\section{Covid-19: AstraZeneca vaccine is approved in EU with no upper age limit}

\author{
Ingrid Torjesen
}

The European Medicines Agency authorised Astra Zeneca's SARS-CoV-2 vaccine for use in all adults aged over 18 on 29 January, just days after German newspapers suggested that the vaccine would be limited to adults aged under 65 because of poor efficacy in older people.

The EMA's Committee for Medicinal Products for Human Use announced that the AstraZeneca and Oxford University vaccine was safe and effective at preventing infection in people from 18 years of age, on the basis of data from four clinical trials conducted in the UK, Brazil, and South Africa. The two doses can be given between four and 12 weeks apart.

The vaccine's safety was shown in all four studies, which included around 24000 people, but the efficacy decision was based on results from only two of the trials. Results from two others were excluded because each had fewer than six cases of covid-19.

Also, only data from patients who received two standard doses of the vaccine between four and 12 weeks apart were included in the final efficacy analysis. This showed a 59.5\% reduction in the number of symptomatic covid-19 cases in people given the vaccine; there were 64 cases of covid-19 with symptoms in 5258 people who received the vaccine and 154 in 5210 people who received the placebo.

German newspapers had claimed on 25 January that the EMA would exclude over 65 s from the vaccine's recommended authorisation because efficacy was less than $10 \%$ in this group. ${ }^{12}$

Bruno Sepodes, vice chair of the EMA committee, told a press conference that most people in the trials were aged between 18 and 55 years and that only $13 \%$ were aged 65 years or older. "Protection in this population is expected based on their immune response and results in younger participants and people given similar vaccines," he said. "The exact level of protection [in this group] cannot be estimated for the time being.” But he emphasised, "There is no reason to expect that this would not have some level of efficacy in that age group.”

The committee will further assess efficacy as the data emerge. In particular, it will evaluate data from a US trial that has enrolled around 30 ooo volunteers and includes a "substantial cohort of elderly people," he said.

The Pfizer-BioNTech and Moderna vaccines have already been authorised for use in Europe, but these present logistical challenges because they are based on mRNA technology and must be stored at very low temperatures. Both are two dose vaccines authorised at a dosing interval of four weeks. Pfizer has also announced that it will temporarily reduce supply to European countries while it upscales production at a factory in Belgium.

The AstraZeneca vaccine is based on an adenovirus and will provide an additional therapeutic tool to EU member states, Sepodes said. The longer dosing interval from four to up to 12 weeks between the first and the second dose will bring additional flexibility to vaccination campaigns in the EU, he said.

Emer Cooke, executive director of the European Medicines Agency, said, "Adenovirus vectored vaccines are easier to handle then mRNA vaccines in terms of transport and storage, and this should simplify the logistics of rolling the vaccine out across the EU and hopefully can provide a boost to vaccinations in the member states."

Germany will offer the AstraZeneca vaccine only to adults up to 64 years after STIKO, the committee that determines how vaccines are used in Germany, recommended on 29 January that it should be used only in this age group because of insufficient data for the over-65s. ${ }^{3}$

Italy's medicines agency authorised the AstraZeneca vaccine for all age groups but recommended that it be administered to people aged between 18 and 55 , with other vaccines to be used in older age groups. ${ }^{4}$

Sepodes said that the EMA's recommendation “does not collide” with STIKO's decision. The EMA says, “It [the AstraZeneca vaccine] can be used; if there are other options those could be preferred in specific situations."

As well as obtaining vaccine through the EU purchasing deal, Germany has procured additional vaccines separately, including an extra 30 million doses of the Pfizer-BioNTech vaccine, which was developed through a German-US research partnership.

Stephen Evans, professor of pharmacoepidemiology at the London School of Hygiene and Tropical Medicine, said that STIKA's decision on use in Germany was made "in a context where supplies of the Pfizer-BioNTech vaccine, for which data in older people show similar efficacy as in younger people, are relatively plentiful. In such a situation it is reasonable to prioritise younger people with one and older people with the other vaccine."

Waschinski G, Brors P, Hofmann S, Siebenhaar H-P. Corona-Impfstoff: Diskussion um Wirksamkeit von Astra-Zeneca-Vakzin bei Senioren. Handelsblatt. 25 Jan 2021. https://www.handelsblatt.com/politik/deutschland/pandemie-bekaempfung-corona-impfstoff-diskussion-um-wirksamkeitvon-astra-zeneca-vakzin-bei-senioren/26849788.html.

2 Keine Zulassung von AstraZeneca für Senioren! Bild. 25 Jan 2021. https://www.bild.de/bild-plus/politik/inland/politik-inland/regierung-fuerchtet-impfstoff-rueckschlag-keine-astrazeneca-zulassung-fuer-senio75065640,view=conversionToLogin.bild.html. 
3 Beschluss der STIKO zur 2. Aktualisierung der COVID-19-Impfempfehlung und die dazugehörige wissenschaftliche Begründung. 29 Jan 2021. https://www.rki.de/DE/Content/Infekt/Epid-

Bull/Archiv/2021/Ausgaben/05_21.pdf.

4 Agenzia Italiana del Farmaco. Autorizzato vaccino AstraZeneca. 30 Jan 2021. https://aifa.gov.it//aifa-autorizzato-vaccino-astrazeneca.

This article is made freely available for use in accordance with BMI's website terms and conditions for the duration of the covid-19 pandemic or until otherwise determined by BMJ. You may use, download and print the article for any lawful, non-commercial purpose (including text and data mining) provided that all copyright notices and trade marks are retained. 